\title{
International Comparison of Global Perceptions
}

\author{
Antonin Ricard ${ }^{1}$, Emmanuelle Reynaud ${ }^{1}$, C Gopinath ${ }^{2} \&$ Parthasarathy Ravilochanan $^{3}$ \\ ${ }^{1}$ CERGAM - IAE Aix-en-Provence, Puyricard, France \\ ${ }^{2}$ Sawyer Business School, Suffolk University, Boston, USA \\ ${ }^{3}$ School of Management, SRM University, Tamilnadu, India \\ Correspondence: Antonin Ricard, CERGAM - IAE Aix-en-Provence, Puyricard, France. Tel: 33-442-280-808. \\ E-mail: antonin.ricard@iae-aix.com
}

Received: March 10, 2012 Accepted: May 3, 2012 Online Published: July 1, 2012

doi: 10.5539/ibr.v5n7p28 URL: http://dx.doi.org/10.5539/ibr.v5n7p28

\begin{abstract}
The recent global economic crisis is affecting people's positions on globalization. In this paper, we examine the views of young managers toward globalization especially in small and medium enterprises. Since globalization has differential impacts in both developed and developing countries, we compare the views of young managers in France and India. We draw upon the social representations theory and its impact on attitudes to identify the differences among young managers. We measure the social profiles of managers (international openness, social background, work environment and education) and link them to social representation. The results show different levels of attitudes according to the manager countries of origin. The results also validate the existence of a link between attitudes and representations which vary according to manager social profiles.
\end{abstract}

Keywords: globalization, social representations, attitude, managers, SME, France, India

\section{Introduction}

The rise of the global economy has given birth to a myriad of studies about the role of managers in international firms. Globalization is a complex concept that has been defined differently at different times. Kherdjemil (2000) and Mucchielli (1998) viewed it as a set of economic strategies in the minds of policymakers. Mittelman (1996) described it as a process induced by changes in the market rather than the result of deliberate policies. In this manner, many scholars have focused on various aspects of globalization and experts, scientists, journalists, politicians and activists have joined the debate to disseminate their views on globalization. In addition to this variability in defining the concept, there is a divergence in the media on the effects of globalization. For instance, the World Business Organization argues that inequalities between rich and poor have decreased and that globalization has contributed to this change (CCI, 2003) (Note 1), while the United Nations Development Program published a Global Report on Human Development in 1999 stipulating that the number of people with incomes less than or equal to 1 dollar had not changed in the previous ten years.

Such differences have led to confusion about the meaning and implications of globalization for most of the population and divided peoples' points of view. Is it possible for people to have clarity in their views in light of these arguments? This is surely rare (World Economic Forum 2002) (Note 2), according to Poeschl (2008), and must affect peoples' positions on globalization in an organization. This question is significant for firms because the manager thinking has an impact on the success of its internationalization mission (Nummela, Saarenketo, \& Puumalainen, 2004). Consequently, the aim of this paper is to better understand manager image of globalization. To enrich the conclusions, it appears to be necessary to examine managers from different countries so that we can make an international comparison. We chose to focus on two countries, a developed country (France) which strongly benefits from globalization but has a negative view about it (Messerlin, 2004) and an emerging market (India) which is in the opposite situation (Drèze \& Sen, 2002; Chopra, 2003). This specific context is extremely interesting since attitudes in both countries toward globalization differ from what their international position would suggest.

The need to study and understand the vision of globalization is decisive for SMEs in particular. Indeed, the leader of an SME plays a significant role by initiating deliberate strategies (Mintzberg, 2008) and the strategic vision is 
both intense and personal in the small firm context. The strategy is created through an intuitive process taking place in the CEO's mind whose vision of the world is orienting future strategy (Mintzberg, 2008). In a crisis period, national markets may become insufficient and the firm's need to go abroad increases. This crucial argument justifies the focusing our study on the globalization vision of Indian and French managers.

To analyze the image of globalization, a literature review $(\S 1)$ is first presented to clarify the concepts of social representations and attitudes studied in this paper. Each point of this analysis will be linked to globalization in order to enrich the problem. We then report an empirical study $(\S 2)$ that deals with our questions.

\section{Literature Review}

\subsection{A Paradoxical View of Globalization}

The KOF Index of Globalization (Note 3) shows a ranking of the most globalized countries according to criteria such as current economic flows, economic restrictions, data on information flows, data on personal contact, and data on cultural proximity. In 2007, France's rank was 6 and India's rank was 82/122. We would therefore expect the French to have a favorable view of globalization given that they are more advanced in their global integration. However, the French do not react well to globalization. Indeed, they do not benefit as much as they could from the opportunities offered on account of protectionist measures, and miss some of the advantages of world trade (Messerlin, 2004) and therefore view the world pessimistically.

On the other hand, although developing countries are discussed extensively in the literature, they are analyzed together, without any distinction. Thus, studying India will bring a fresh and detached view that is distinct from other developing countries. Moreover, numerous authors have shown that globalization highlights negative issues such as illiteracy, poverty, and premature mortality (Drèze \& Sen 2002; Chopra 2003). Yet paradoxically, India is very favorable to globalization (Chopra, 2003).

To conclude, it appears that there is a paradox between the French who have quite an unfavorable perception of globalization while they reap the benefits, and Indians who have favorable views of it while they are suffering from severely negative effects. That's the reason that a comparative analysis of perceptions of young Indian and French managers will bring a new perspective to the origins of manager attitudes and representation toward globalization.

\subsection{Social Representations of Globalization}

This study required young managers' opinions on globalization in order to understand how views are formed and to anticipate cognitive functions. This is why we chose to tackle the subject from the perspective of social representations, which was defined by Roussiau and Bonardi (2001) as "an organization of socially constructed views with respect to a given object from a set of social communications, to control the environment and to integrate elements according to their symbolic or its group affiliation" (p19).

Very few researchers have focused on the social representation of globalization. They have identified a limited number of areas associated with globalization. Thus, students from Brest (France) strongly associate it with the economy, trade and politics. In Goiás (Brazil) it is the economy, politics and falling physical barriers. Students from Mexico associate it strongly with the economic area (Humberto \& Campos, 2008). Another study led by Viaud (2008) surveyed respondents engaged in international missions. Nine themes were identified by this survey: psychology, politics, values and ideas, the economy, social progress and technology, information and communication, environment and health, culture and diverse. In order to focus on the areas of a firm's interest, we can remove some inappropriate domains from this list (psychology and diverse). Moreover, values and ideas are linked to attitude and can also be removed. Thus, six fields remain: the economy and society, culture, politics, progress and technology, information and communication, environment and health.

To better enable the decomposition of globalization appropriate to the business environment, we chose to apply the domains proposed by Gopinath (2008, 2012). He identified the economy, business, and political, physical and social domains as a comprehensive decomposition of globalization and matches the two previous studies.

Table 1 summarizes the results from empirical and theoretical papers. 
Table 1. Study results of representations toward globalization

\begin{tabular}{lll}
\hline Methods & Results & Authors \\
\hline Empirical & $\begin{array}{l}\text { Students identify four areas related to globalization: economics, politics, commerce / } \\
\text { business, and physical barriers }\end{array}$ & Humberto \& Campos, \\
& $\begin{array}{l}\text { Employees identify nine areas related to globalization: psychology, politics, values and } \\
\text { Empirical }\end{array}$ & $\begin{array}{l}\text { Viaud, 2008 } \\
\text { ideas, economic and social progress and technology, information and communication, }\end{array}$ \\
& $\begin{array}{l}\text { environment and health, culture and a miscellaneous category } \\
\text { Theoretical }\end{array}$ & Globalization broken down into 5 areas: Economics, Business, Physical, Politics, Social \\
\hline
\end{tabular}

\subsection{Impact of Social Representations on Attitudes toward Globalization}

Abric's definition of social representations ("product and process of mental activity by which an individual or a group reconstitutes the reality facing it and attaches a specific meaning to it” (Abric, 1988, p. 64)) shows the role of attitudes in the allocation of "a specific meaning". Thus, attitude, defined by Doise as a position for the "evaluation of a social entity" (Doise, 2003, p. 242), is a component of social representations, which will be associated with the individual's meaning of the social object.

Viaud, Uribe Patiño, \& Acosta Ávila (2007), measured student representations and attitudes to globalization. They classified respondents in two groups: Supporters (associating globalization with technological advances, the unification and communication) and opponents (gap between rich and poor, loss of cultural specificity and capitalism). Following these results, in accordance with the decomposition of the globalization that was presented earlier, we can expect that the representations of the supporters will be linked to the positive aspect of the physical domain and those of the opponents to the negative aspects of the economy and social fields.

These authors also showed, using a different method, that supporter representations include the economy, technology and union; and opponents identify as central elements the United States, poverty, domination, capitalism, the loss of identity, inequality and uniformity.

Using a similar method on an international cohort, Viaud (2008) found that the strongest supporters evoke progress and a new world (Goiás, Brazil). Moderate supporters evoke a better world (Porto and Tunis). Opponents can be classified in three categories: those who link globalization with the "economy of poverty" (p130) (Aix-en-Provence - France and Mexico); those who associate it with "loss of themselves" (p130) and those who refer to social issues (Brest, France). Finally, indifferent and resigned respondents refer to "world domination" (p130).

The various methods used by authors have led to slightly different results. Although the fields related to globalization may vary, the results are not contradictory, and a common reading of these publications is used to classify subjects as follows: globalization supporters describe the positive side of technological advances contained in the physical domain. Opponents are more influenced by the negative sides of globalization, particularly in the fields of economy and society. It is therefore possible, at the end of this research, to provide a direction to the attitude-representations relationship. Given the differences related earlier in this document, young Indian and French managers must have very different views on globalization. The questionnaire proposed in our research will help to analyze whether these suggestions are relevant to our two samples.

The following research questions summarize the above discussion:

RQ1: Globalization supporters are associated with social representation levels that are different from those of globalization opponents.

RQ2: Globalization supporters have a favorable view of the physical and the economic domains.

RQ3: Globalization opponents have an unfavorable view of the political, economic and the social domains.

RQ4: The relationship between attitude and social representations varies according to a manager's origin.

Manager origin is not the only parameter to be considered while studying social representation-attitude link. Differentiating social groups accurately contributes to the analysis of commonalities throughout our research samples. Therefore, having a large number of demographic questions will improve the overview of the sample's characteristics and will help to find variables that affect these relationships. This will help reduce the sample's variance by differentiating the types of people with the use of control variables. Assuming that social profile breaks down an individual's social representations, we seek to identify all the parameters that are linked to the position within the referential society.

Three studies help to identify the variables we ought to control: 
- Living conditions and the ability to have access to a certain type of culture that serves as a guide for information, therefore affect social representations (Dorra, 2008). This gives the first parameters to control: variables characterizing international openness and those conditioning its social environment.

- Hierarchical or ideological factors modulate the differences between groups (Doise, 1982). Demographical variables must therefore include factors about the subject's position in the company, i.e., the working environment.

- Education has a role in reaching and understanding information. It therefore particularly influences representation design and has an impact on establishing attitudes toward globalization (Hainmueller \& Hiscox, 2006). Hence, manager education must be monitored.

These studies provided four groups of variables that are likely to play a role on the attitude-representation link and help to identify the following research questions:

RQ5: Variations in the international openness, social environment, work environment and education of young managers are associated with variations in attitude and levels of representation.

Table 2 summarizes the previous research questions.

Table 2. Research question summary

\begin{tabular}{cl}
\hline Research questions & \multicolumn{1}{c}{ Content } \\
\hline RQ1 & $\begin{array}{l}\text { Globalization supporters are associated with social representation levels that are different from those of } \\
\text { globalization opponents } \\
\text { RQ2 }\end{array}$ \\
RQ3 & Globalization supporters have a favorable view of the physical and economic domain \\
RQ4 & The relationship between attitude and social representations varies according to a manager's origin \\
RQ5 & Variations in the international openness, social environment, work environment and education of young \\
& managers are associated with variations in attitude and levels of representation \\
\hline
\end{tabular}

\section{Research Design}

A questionnaire was used to collect data from the young managers. Since no previous study has evaluated social representations toward globalization, we designed a new scale for this exploratory study. Items were evaluated on a five-point interval scale ranging from "Strongly agree" to "Strongly disagree". We were guided by the recommendations of Malhotra, Agarwal and Peterson (1996) in the design. Thus, we checked the functional equivalence of the main term of the study (“Globalization”). Moreover, the questionnaire was created in English and translated into French and then reverse translated into English to ensure a perfect correspondence of the questions. The questionnaire was first tested in France. It was then assessed, improved and used to collect data on a second sample. The Indian questionnaire was completed in English as it is the norm in India (the University Fellows International Research Consortium led by David Ralston does the same in its numerous studies).

\subsection{Contents of the Questionnaire}

As stated in the literature review, the measurement of social representations must include domains that capture the meaning of globalization for young managers. Hence, items must refer to one of the 5 pre-identified domains and to attitude. They are borrowed from broad themes in the literature, as follows:

- Economy: Edwards (2006), Adler and Mittelman (2004),

- Business: Gupta and Govindarajan (2002), Nummela et al. (2004), Bouquet (2005), Arora et al. (2004), Zdravkovic (2007),

- Political: Venard and Hanafi (2008), Nielsen (2007),

- Physical: Zdravkovic (2007), Gopinath (2008), Adler and Mittelman (2004), Khilji (2004),

- Social: Gupta and Govindarajan (2002). Edwards (2006), Adler and Mittelman (2004), Taewon and Ik-Whan (2002), Gopinath (2008),

- Attitude: Arora et al. (2004), Gupta and Govindarajan (2002), Adler and Mittelman (2004), Nummela et al. (2004), Bouquet (2005). 
The attitudinal statements include issues involving the individual's position on globalization and force him/her to take a position. This part was constructed to reflect a personal identification ('I think' or 'I believe') associated with a specific aspect of globalization.

The control variables were placed at the end of the questionnaire. They measure the four groups of variables previously identified (international openness, social background, work environment and education) to which we added age and gender.

\subsection{Sample Characteristics}

The French sample was built on a follow-up process which is known to be efficient to reach a specific population (Royer \& Zarlowski, 2007; Jolibert \& Jourdan, 2006). The Indian sample was composed of young students based in India. The questionnaire was sent during the global economic crisis and there was a two-month gap between the French and the Indian data collection.

Sample characteristics are provided in Table 3.

Table 3. Sample characteristics

\begin{tabular}{|c|c|c|c|}
\hline & & France & India \\
\hline General & Sample size & 79 & 56 \\
\hline \multirow[t]{2}{*}{ Informations } & Gender & 33\% Female & $35 \%$ Female \\
\hline & Age & $86 \%$ are under 40 years & $100 \%$ are under 40 years \\
\hline Work Environment & Work experience & $69 \%$ under 10 years of experience & $100 \%$ under 10 years of experience \\
\hline \multirow[t]{2}{*}{ Education } & Educational level & $72 \%$ have at least 5 years of study & $85 \%$ have at least 5 years of study \\
\hline & Field of study & $\begin{array}{l}86 \% \text { attended courses in management or } \\
\text { engineering }\end{array}$ & $\begin{array}{l}84 \% \text { attended courses in management } \\
\text { or engineering }\end{array}$ \\
\hline International & Number of countries visited & $60 \%$ visited between 4 and 10 countries & $40 \%$ visited between 4 and 10 countries \\
\hline \multirow[t]{3}{*}{ Openness } & Number of countries lived in & $50 \%$ have lived abroad for more than one year & $\begin{array}{l}40 \% \text { have lived abroad for more than } \\
\text { one year }\end{array}$ \\
\hline & Number of spoken languages & $87 \%$ speak more than one language & $90 \%$ speak more than one language \\
\hline & Parent(s) immigrant (s) & $33 \%$ have at least one immigrant parent & $50 \%$ have at least one immigrant parent \\
\hline \multirow[t]{2}{*}{ Social Environment } & Income & $77 \%$ between $€ 30$ and $€ 60 \mathrm{k}$ & N/A \\
\hline & Parents education & 74\% have parents with studies & $100 \%$ have parents with studies \\
\hline
\end{tabular}

The two samples were made up of young managers with low experience and high level social background:

The field of study was quite concentrated: the majority of respondents ( $86 \%$ of the French and $84 \%$ of the Indians) attended courses in management or engineering. This is not surprising, since these courses provide rapid access to managerial positions.

International openness was broad (60\% of the French and $40 \%$ of the Indian respondents had visited between 4 and 10 countries; $87 \%$ and $90 \%$ respectively spoke more than one language, $33 \%$ and $50 \%$ respectively had at least one immigrant parent). $50 \%$ of the respondents have lived abroad for more than two years and that figure would increase if we included the students who went abroad for a semester.

The social environment is high (74\% of the French have parents who are educated with $100 \%$ for the Indians).

Both samples are quite similar. They contain young and highly educated managers who have significant international experience.

\section{Results}

Individual scores are calculated by summing up the items in each domain followed by a comparison of the French and Indian scores.

These results show that there is a significant difference in the attitude toward globalization between the French and Indian respondents. There were significant differences in how they perceived the trends in the economic, the physical, and the social domains. The relationship between attitude and social representations varies with manager origin, so RQ 4 is validated. 
Table 4. Score differences

\begin{tabular}{llll}
\hline Variable & Mean French $(\mathrm{n}=79)$ & Mean Indian $(\mathrm{n}=56)$ & $t$ value (Sign.) \\
\hline Attitude & 3.6 & 2.6 & $-7.5(p=0.00)$ \\
Business & 3.8 & 4.0 & \\
Economic & 3.7 & 3.9 & $1.6(p=0.1)$ \\
Political & 3.1 & 3.5 & \\
Physical & 2.6 & 3.3 & $-4.3(p=0.00)$ \\
Social & 2.7 & 3.9 & $1.8(p=0.1)$ \\
\hline
\end{tabular}

The attitude score was then binary encoded so that we could crosstab the attitude and the domain scores for each country. The cutoff point chosen was the mean of the considered group. The significance of the differences was validated by a $t$-test (only significant values are given in the tables). The results are summarized in the following table.

Table 5. Representations-Attitudes Relationship

\begin{tabular}{|c|c|c|c|c|c|c|c|c|c|c|c|}
\hline & & \multicolumn{5}{|c|}{ French scores } & \multicolumn{5}{|c|}{ Indian scores } \\
\hline & & Business & Economic & Political & Physical & Social & Business & Economic & Political & Physical & Social \\
\hline \multirow{3}{*}{ Attitude } & Unfavorable & 3.7 & 3.0 & 3.6 & 2.4 & 2.6 & 3.9 & 3.5 & 3.5 & 3.3 & 3.1 \\
\hline & Favorable & 4.0 & 3.1 & 3.8 & 2.7 & 2.47 & 3.9 & 3.5 & 3.6 & 3.2 & 3.0 \\
\hline & Difference significance & 0.01 & & & 0.05 & & & & & & \\
\hline
\end{tabular}

French sample: Analyzing this table, we find that a favorable attitude is associated with a high business score and a high physical score. An unfavorable attitude toward globalization is associated with low business and physical scores. This leads to three comments: these results validate RQ 1: the attitudes and representations are linked to the total sample; RQ2, which assumed a link with the physical and economic domains, is partially rejected; RQ3, which assumed a link with the political, economic and social domains, is rejected.

Indian sample: Analyzing this table, we find that there are no significant differences between the attitude scores and the representation scores. This is probably due to the numerous minorities in India that might smooth out differences.

In both samples, attitude is not significantly associated with the economic domain, which suggests that the young managers surveyed in our sample have different perceptions of the impact of the economic side of globalization.

These results were then refined using the demographic variables that were introduced to differentiate respondents. To simplify interpretation of the results, demographic scores were binary encoded in order to separate the demographic variables that were below the average of the others (at least for the demographical variables that can allow such a cut). Representation scores were then reviewed for each demographic variable. The results are grouped in the summary tables presented below. Some demographic variables were removed since they could not be split.

Based on significant differences in demographic dimensions, we suggest that there is a link between demographic variables and the attitude-representation relationship for both samples (RQ5 validation). Furthermore, these results again confirm that the attitudes and representations of young managers are linked.

Table 6 shows that when the level of a demographic variable is low, the attitude toward globalization is poorly associated with the representation. This suggests that a good level in the four latent variables (international openness, social environment, work environment and education) is associated with the different domains of globalization, and therefore better captures the composition of globalization. 
Table 6. Representations-Attitudes relationship according to demographic parameters

\begin{tabular}{|c|c|c|c|c|c|c|c|}
\hline & & \multicolumn{6}{|c|}{ Score } \\
\hline & & Attitude & Business & Economic & Political & Physical & Social \\
\hline \multirow[t]{3}{*}{ Age } & High & 3 & 3.9 & 3.3 & 3.6 & 3.1 & 2.9 \\
\hline & Low & 3.5 & 3.8 & 3.1 & 3.7 & 2.5 & 2.7 \\
\hline & Difference significance & 0.01 & & 0.05 & & 0.01 & 0.08 \\
\hline \multirow[t]{3}{*}{ Work experience } & High & 3 & 3.9 & 3.4 & 3.6 & 3.1 & 2.9 \\
\hline & Low & 3.5 & 3.8 & 3.1 & 3.6 & 2.5 & 2.7 \\
\hline & Difference significance & 0.01 & & 0.01 & & 0.01 & 0.05 \\
\hline \multirow[t]{3}{*}{ Educational background } & business & 3.2 & 3.9 & 3.4 & 3.6 & 2.9 & 2.8 \\
\hline & engineering & 3.3 & 3.8 & 3 & 3.8 & 2.9 & 2.8 \\
\hline & Difference significance & & & 0.01 & 0.01 & & \\
\hline \multirow[t]{3}{*}{ Number of countries traveled in } & High & 2.7 & 4 & 3.5 & 3.6 & 3.3 & 3.1 \\
\hline & Low & 3.5 & 3.8 & 3.1 & 3.7 & 2.6 & 2.7 \\
\hline & Difference significance & 0.01 & & 0.01 & & 0.01 & 0.01 \\
\hline \multirow[t]{3}{*}{ Number of countries lived in } & High & 3 & 3.9 & 3.4 & 3.6 & 3 & 2.9 \\
\hline & Low & 3.6 & 3.9 & 3 & 3.7 & 2.5 & 2.8 \\
\hline & Difference significance & 0.01 & & 0.01 & & 0.01 & \\
\hline \multirow[t]{3}{*}{ Number of spoken languages } & High & 3.6 & 3.7 & 3.1 & 3.7 & 2.6 & 2.6 \\
\hline & Low & 3.7 & 3.9 & 3.1 & 3.8 & 2.5 & 2.7 \\
\hline & Difference significance & & & 0.06 & & & \\
\hline \multirow[t]{3}{*}{ Non immigrant parent } & High & 2.8 & 3.9 & 3.3 & 3.4 & 3.5 & 3.3 \\
\hline & Low & 2.5 & 3.95 & 3.6 & 3.6 & 3.2 & 3 \\
\hline & Difference significance & & & & & & \\
\hline \multirow[t]{3}{*}{ Parent educational level } & High & 3.6 & 3.8 & 3.2 & 3.6 & 2.4 & 2.7 \\
\hline & Low & 3.6 & 3.9 & 3.0 & 3.8 & 2.6 & 2.7 \\
\hline & Difference significance & & & & & & \\
\hline
\end{tabular}

To conclude, the following table summarizes the research questions and their validation:

Table 7. Research question validation

\begin{tabular}{ll}
\hline Research questions & Content \\
\hline RQ1 & $\begin{array}{l}\text { Globalization supporters are associated with social representation levels that are different from } \\
\text { those of globalization opponents } \\
\text { RQ2 }\end{array}$ \\
RQ3 & Globalization supporters have a favorable view of the physical and economic domain \\
RQ4 & The relationship between attitude and social representations varies according to a manager's origin Validated \\
RQ5 & Variations in the international openness, social environment, work environment and education of Validated \\
& young managers are associated with variations in attitude and levels of representation \\
\hline
\end{tabular}

\section{Discussion}

First, let us examine the results that support the theory. As shown by Tafani (1997) and Doise \& Palmonari (1986) with a sample of students, the components of the representations are related to attitudes. Tables 5 and 6 address this issue and significant results were obtained in all of these cases. This is the first demonstration that the components of the representations can be associated with a specific attitude toward globalization by young managers from different countries of origin.

One of the main points of our research was to propose a decomposition of globalization based on five domains: business, economic, political, physical and social. Our study of a young manager's social group successfully applied this theory (all of these domains are linked to young manager attitudes across different demographic variables). It is interesting to note that the relationship of the business aspect of globalization with attitude was strong among young French managers. This would suggest that French representations of globalization are essentially built in a professional context. 
We also found that attitude and representation scores vary according to different variables that assess the social profile. This was seen by examining the fluctuations in the variables that measure the social profile (international openness, social environment, work environment and education). These results agree with Dorra (2008) who identified differences in social representations according to social profile, and Scheve \& Slaughter (2001) who also noted differences in attitudes between social classes, comparing low and high-level educated individuals.

Some of our results disagree with the current literature. Scheve \& Slaughter (2001) predicted that attitude was intimately connected with the poor health of the labor market. Given current world economic instability, we expected young managers' attitudes toward globalization to be low. Our results show an overall favorable attitude of the French sample (mean score of attitude greater than the arithmetic mean), so we cannot fully support this thesis. The people surveyed by Scheve and Slaughter were significantly different from those in our study (their sample of Americans included managers, manual workers, administrative personnel, etc...). Perhaps, as the current economic crisis began in the United States in 2008, that country is much more affected than France, which could partly explain the relatively high attitude level. Moreover, Scheve and Slaughter included workers from various social categories, including jobs which suffered the most from the crisis. We could not check the attitude level before the crisis in our research and that is why a longitudinal study has to be undertaken to demonstrate that the attitude level in the current context is different from the level after the crisis.

Earlier, we referred to the Foreign Policy Magazine ranking, the Messerlin (2004) study on the bad reactions of the French to globalization and Rudra's (2005) results showing that workers in less developed countries are often the losers of globalization. This led us to raise a paradox in the first part of this paper about the French who have quite an unfavorable perception of globalization while they reap the benefits (Messerlin, 2004) and Indians who have favorable views on it while they suffer severely negative effects (Drèze \& Sen, 2002; Chopra, 2003). According to this observation, we expected the French to have a lower attitude than the Indians. This is not the case in our sample, which can be explained by the unequal consequences of the crisis: India was more affected than France (Note 4). Hence we suggest that the results presented in this paper cannot easily be generalized to other countries.

What could be the practical implication of such findings for managers? Several scholars have argued that managers need to have a global mindset for their organizations to take advantage of globalization (Tichy et al., 1992; Bartlett \& Ghoshal, 1992; Rhinesmith, 1992; Kefalas, 1998). A global mindset was defined by Gupta and Govindarajan (2002) as an openness and an awareness of markets and cultural diversity. This new type of manager (Bartlett \& Ghoshal, 1992) plays a crucial role in a global context (Kedia \& Mukherji, 1999) and deserves serious study. Furthermore, an international environment creates new constraints for managers. Thus, they have to integrate the whole business in general, regional/national pressures, and global functions. This is why they cannot ignore any of the variables linked to globalization. Our research is promising and informs leaders and human resource managers who would like to hire employees who match global constraints. This must be done by better understanding the link between attitudes and representations of globalization and the positions toward globalization determinants, which has not been adequately studied by earlier researchers.

Often, information which is contrary to a manager's representations will contribute to its transformation, and thus influence attitude (Flament, 2003). Therefore, it is of value to identify demographic variables that are linked to different domains. Table 6 can help to choose a manager with specific characteristics that are in accordance with the job requirements. This will help understand which kind of information will affect the attitudes of managers.

The Nummela et al. (2004) study is one of the few studies that quantified the impact of global thinking on a company or individuals and emphasized the use of having a global way of thinking. The experience and the sector of a manager's company were shown to be success factors in the internationalization of Finland's companies. In addition, the authors showed the positive impact of these determinants on the global mindset of a company's members and its positive impact to improve performance on international markets. Another study led by Arora et al. (2004) also found a positive relationship between a manager's global mindset and internationalization success. They stated that companies should make more efforts in training managers who are assigned international duties.

As attitudes affect individual behavior (Kraus, 1995), it is essential to analyze the relationship between demographic variables and attitude so that we can draw an adequate profile adapted to international missions. This profile should have high international openness, social background, work environment experience and education. According to our study, the most important factors appear to be educational background and parents' education.

\section{Conclusion}

This exploratory study has enriches knowledge of manager attitudes and representations toward globalization. Focusing on young managers emphasizes their important role in international corporate activities. 
The results are consistent with the literature on social representations and additional results have confirmed the relationship between demographic variables (international openness, social environment, work environment and education) and representations of globalization.

However, it should be noted that there is a limitation owing to the low number of respondents. This limits the generality of the results but is sufficient for the preliminary needs of this exploratory study.

Finally, globalization studies show weak representations in periods of positive growth (Poeschl, 2008; Dorra, 2008; Leiser, 2008). Moreover, the image of globalization has been improving with time so far (Ribeiro \& Poeschl, 2008). These two statements justify the great interest to study positions toward globalization in the context of crisis. Since a poor representation of globalization could induce a psychological barrier toward internationalization, this subject is decisive in SMEs which are known to be greatly influenced by the CEO's vision, especially given that the current period had provided much bad news on the shocking consequences of globalization which alter positions on globalization (Ribeiro \& Poeschl, 2008). Our results should be complemented with a study measuring the evolution of attitudes and representations after the current crisis.

\section{References}

Abric, J. C. (1988). Coopération, conflit et représentations sociales. Cousset: Del Val.

Bartlett, C. A., \& Ghoshal, S. (1992). What is a global manager? Harvard Business Review, 70(5), 124-132.

Chopra, R. (2003). Neoliberalism as Doxa: Bourdieu's theory of the state and the contemporary Indian discourse on globalization and liberalization. Cultural studies, 17(3-4), 419-444. http://dx.doi.org/10.1080/0950238032000083881

Doise, W. (1982). L'explication en psychologie sociale. Paris: PUF.

Doise, W. (2003). Attitudes et représentations sociales. Les représentations sociales. Paris: PUF.

Doise, W., \& Palmonari, A. (1986). L'étude des représentations sociales. Neuchatel: Delachaux et Niestlé.

Dorra, B. A. (2008). Etude quantitative de la stabilité de la représentation sociale de la mondialisation. In J. Viaud \& G. Poeschl (Eds.), Images de la mondialisation / La construction sociale d'une représentation (pp. 159-177). Rennes: PUR.

Drèze, J., \& Sen, A. (2002). India: development and participation (Vol. 1-1). Oxford: Oxford University Press.

Flament, C. (2003). Structure et dynamique des représentations sociales. les représentations sociales. Paris: PUF.

Gopinath, C. (2008). Globalization: A multidimensional system. Thousand Oaks, CA: Sage.

Gopinath, C. (2012). A systems framework for globalisation. International Journal of Business and Globalisation, 8(3), 316-330. http://dx.doi.org/10.1504/IJBG.2012.046208

Gupta, A. K., \& Govindarajan, V. (2002). Cultivating a global mindset. Academy of Management Executive, 16(1), 116-126. http://dx.doi.org/10.5465/FAME.2002.6640211

Hainmueller, J., \& Hiscox, M. J. (2006). Learning to Love Globalization: Education and Individual Attitudes Toward International Trade. International Organization, 60(2), 469-498. http://dx.doi.org/10.1017/S0020818306060140

Humberto, P., \& Campos, F. (2008). La représentation sociale de la mondialisation: son image, ses promesses, ses illusions. In J. Viaud \& G. Poeschl (Eds.), Images de la mondialisation / La construction sociale d'une représentation (pp. 133-157). Rennes: PUR.

Jolibert, A., \& Jourdan, P. (2006). Marketing research: méthodes de recherche et d'études en marketing. Gestion sup (Paris). Paris: Dunod.

Kedia, B. L., \& Mukherji, A. (1999). Global Managers: Developing A Mindset For Global Competitiveness. Journal of World Business, 34(3), 230-251. http://dx.doi.org/10.1016/S1090-9516(99)00017-6

Kefalas, A. G. (1998). Think Globally, Act Locally. Thunderbird International Business Review, 40(6), 547-562. http://dx.doi.org/10.1016/S1090-9516(99)00017-610.1002/(SICI)1520-6874(199811/12)40:6<547::AID-TI E3>3.0.CO;2-F

Kherdjemil, B. (2000). Territoires, mondialisation et redéveloppement. Paris: L'Harmattan.

Kraus, S. J. (1995). Attitudes and the Prediction of Behavior: A Meta-Analysis of the Empirical Literature. $\begin{array}{llll}\text { Personality and Social Psychology } & \text { Bulletin, } & \text { 21(1), }\end{array}$ http://dx.doi.org/10.1016/S1090-9516(99)00017-610.1177/0146167295211007 
Leiser, D. (2008). La mondialisation vue depuis Israël. Images de la mondialisation / La construction sociale d'une représentation. In J. Viaud \& G. Poeschl (Eds.), Images de la mondialisation / La construction sociale d'une représentation (pp. 79-91). Rennes: PUR.

Malhotra, N. K., Agarwal, J., \& Peterson, M. (1996). Methodological issues in cross-cultural marketing research: A state-of-the-art review. International Marketing Review, 13(5), 7-43. http://dx.doi.org/10.1016/S1090-9516(99)00017-610.1108/02651339610131379

Messerlin, P. A. (2004). La France profite mal de la mondialisation. Sociétal, 46, 108-112.

Mintzberg, H. (2008). Le management: voyage au centre des organisations. (J.-M. Béhar \& N. Tremblay, Trans.) (Vol. 1-1). Paris: Ed. d'Organisation.

Mittelman, J. H. (1996). Globalization, critical reflections. International Political Economy Yearbook. Boulder: Lynne Rienner.

Mucchielli, J.-L. (1998). Multinationales et mondialisation. Paris: Seuil.

Nummela, N., Saarenketo, S., \& Puumalainen, K. (2004). A Global Mindset - A Prerequisite for Successful Internationalization?. Canadian Journal of Administrative Sciences, 21(1), 51-64. http://dx.doi.org/10.1016/S1090-9516(99)00017-610.1111/j.1936-4490.2004.tb00322.x

Poeschl, G. (2008). Stabilité et variations dans les représentations sociales de la mondialisation. In J. Viaud \& G. Poeschl (Eds.), Images de la mondialisation / La construction sociale d'une représentation (pp. 101-118). Rennes: PUR.

Rhinesmith, S. H. (1992). Global Mindsets for Global Managers. Training \& Development, 46(10), 63-68.

Ribeiro, R., \& Poeschl, G. (2008). Croyance dans un monde juste et mondialisation. In J. Viaud \& G. Poeschl (Eds.), Images de la mondialisation / La construction sociale d'une représentation (pp. 189-203). Rennes: PUR.

Roussiau, N., \& Bonardi, C. (2001). Les représentations sociales: état des lieux et perspectives. Psychologie et sciences humaines. Sprimont: Mardaga.

Royer, I., \& Zarlowski, P. (2007). Echantillons. Méthodes de recherche en management. Gestion sup (Paris). Paris: Dunod.

Rudra, N. (2005). Are Workers in the Developing World Winners or Losers in the Current Era of Globalization?. $\begin{array}{llll}\text { Studies in } & \text { Comparative International }\end{array}$ http://dx.doi.org/10.1016/S1090-9516(99)00017-610.1007/BF02686298

Scheve, K. F., \& Slaughter, M. J. (2001). Globalization and the perceptions of American workers. Washington, D.C.: Institute for International Economics.

Tafani, E. (1997). Attitudes et représentations sociales: de l'ancrage psychologique l'ancrage sociologique. Aix Marseille 1, Psychologie, Aix en Provence.

Tichy, N., Brimm, M., Charan, R., \& Takeuchi, H. (1992). Leadership Development as a Lever for Global Transformation. New York: John Wiley \& Sons.

Viaud, J. (2008). Représentations de la mondialisation chez des actifs de différents pays. In J. Viaud \& G. Poeschl (Eds.), Images de la mondialisation / La construction sociale d'une représentation (pp. 119-132). Rennes: PUR.

Viaud, J., Uribe Patiño, F. J., \& Acosta Ávila, M. T. (2007). Représentations et lieux communs de la mondialisation. Bulletin de psychologie, 60(487), 21-33.

\section{Notes}

Note 1. World Economic Forum, 2002, Global Public Opinion on Globalization.

Note 2. Nouvelles données sur la mondialisation, 2003, la pauvreté et la répartition des revenus, Chambre de Commerce Internationale.

Note 3. http://globalization.kof.ethz.ch/.

Note 4. Study from Regus “Business Tracker” (2009) examining 11000 managers from 15 countries. 